\title{
Legal Policy and Legal Culture in the System for Public Administration and Judiciary in the Kyrgyz Republic
}

\section{Bakytbek Batyrbaev1, Gulnara Aidarbekova², Aidai Toktombaeva3 ${ }^{3}$ Tolkun Salybekova1, Tamara Ganieva2 ${ }^{2}$, Kuldysheva Gulsara ${ }^{4}$, Zhypargul Abdullaeva ${ }^{5^{*}}$ (1)}

\author{
${ }^{1}$ Department of Criminal and Law Procedure, Kyrgyz National University Named after J. Balasagyn, Bishkek, Kyrgyzstan \\ ${ }^{2}$ Department of Theory and History of Government Law, Kyrgyz National University Named after J. Balasagyn, Bishkek, \\ Kyrgyzstan \\ ${ }^{3}$ Department of Constitutional and Administrative law, Kyrgyz National University Named after J. Balasagyn, Bishkek, Kyrgyzstan \\ ${ }^{4}$ Department of Theory and History of Government Law, Osh State University, Osh, Kyrgyzstan \\ ${ }^{5}$ Science and Research Department, Osh State University, Osh, Kyrgyzstan \\ Email: *jypar.science@oshsu.kg
}

How to cite this paper: Batyrbaev, B., Aidarbekova, G., Toktombaeva, A., Salybekova, T., Ganieva, T., Gulsara, K., \& Abdullaeva, Z. (2021). Legal Policy and Legal Culture in the System for Public Administration and Judiciary in the Kyrgyz Republic. Open Journal of Social Sciences, 9, 53-61.

https://doi.org/10.4236/jss.2021.97005

Received: June 17, 2021

Accepted: July 11, 2021

Published: July 14, 2021

Copyright (c) 2021 by author(s) and Scientific Research Publishing Inc. This work is licensed under the Creative Commons Attribution International License (CC BY 4.0).

http://creativecommons.org/licenses/by/4.0/

\begin{abstract}
This article examines the problems of legal policy in the Kyrgyz Republic system of public administration, the role of ongoing reforms in this area, the place of the judiciary in the mechanism of the government, the importance of a legal culture of participants in public relations based on the law rules. The importance of the tasks assigned to the government bodies, courts and legal entities affecting the rights, freedoms and legitimate interests of citizens, determining the special position of the court in the government mechanisms. Research aim is to investigate legal policy and culture in the public administration system and judiciary in the Kyrgyz Republic according to Kyrgyz Republic Laws and Decrees. Research results in this article based on historical comparative, formal logical, general and historical law methods and on literature analysis.
\end{abstract}

\section{Keywords}

Legal Policy, Public Administration, Reform, Judiciary, Judicial Protection, Liability of Legal Entities, Jury, Legal Culture, Citizens' Trust

\section{Introduction}

The principle for the development of public administration (Marques et al., 2021) in the digital age is the transition to an open service model, the main role 
of which is to develop and ensure transparent rules of the game, equality and security for all participants, maintain critical infrastructure and gradually transfer the functions of direct provision of services to public and private organizations (Ganieva, 2019). The challenges faced by modern Kyrgyzstan, political and some socio-economic instability of the stage of unfinished reforms put forward increased requirements for the quality of public administration in the legal policy of the republic.

The public administration system, as stated in the "National Strategy and Development Strategy of the Kyrgyz Republic for 2018-2040", should be focused on the needs of each person, which governance of the country will be based on the participation of every Kyrgyz citizen and entrusted to the best representatives of Kyrgyzstan, who combine professional competencies and high moral and moral qualities (Ministry of Foreign Affairs of the Kyrgyz Republic, 2018).

One of the indicators and factors that determine effectiveness in the management system is the degree of duplication of management functions. Despite the ongoing administrative reform in the system of government bodies, the existence of republican, regional and district government levels in a unitary government, like Kyrgyzstan, with a relatively small population and at the same time with a large budget deficit indicates the presence of unnecessary intermediate links with duplicating functions. This leads to irrational spending of budgetary funds and a lot of time in the course of making and implementing government decisions (Ukushev, 2018).

This was noted at a meeting of the Interdepartmental Working Commission for the Development of Proposals for Reforming the System of Government Agencies on November 18, 2020, where the inefficiency of the government system, duplication of functions, and inconsistency with official duties were noted (Amanbaev, 2020).

In the literature, as a rule, it is noted about the inadmissibility of duplication of the same functions (Rossinsky, 2007) by different executive authorities. But the duplication of powers, in particular supervisory powers, leads to a decrease in the efficiency of the management system. Public administration as an activity differs significantly from other types of administration, primarily in that it is implemented with the help of government power, government bodies and customary law (Kuldysheva et al., 2021). The priority role here is played by political leadership, law and legal culture, which is a concentrated expression of the public interests of social groups and citizens.

\section{Research Methods}

Research results in this article are based on historical comparative, formal logical, general and historical law methods and on literature analysis. In the general method, the evolutionary or gradual development of law, the improvement of legal activity, lawmaking and legal technology, and at the same time, a critical understanding of the created and functioning law was marked by the 
emergence of a special type of social activity, scientific and doctrinal, aimed at understanding the general laws of legal life and law evolution (Russian Law Academy of the Ministry of Justice of the Russian Federation, 2021). Historical comparative method based on information by comparing historical and legal sources; formal logical method gain information based on formal logical methods and techniques exploring the outer law, its sources, typology, classification of legal phenomena and processes and express the possibility of involving the inner essence of law (Napalkova, 2018). General and historical law method approach manifested in the direction of scientific knowledge from the present to the past.

\section{Government Administration Mechanisms}

Consequently, the effectiveness of public administration should be considered in the context of the implementation of a particular legal policy, the impact of government bodies on public life. Separation of powers is a characteristic feature of the rule of law, as well as a guarantee of its full-fledged functioning. Therefore, a significant role is assigned to the system of checks and balances, which is at the disposal of all three independent branches of government, so that, when trying to exceed its powers, each of them could stop the other (Asankulova, 2015). In the mechanism of government administration, the judiciary functions as a tool for verifying the legality and validity of actions and orders of executive government bodies power, municipal authorities and their officials, actions and orders of public associations, commercial organizations and their leaders by considering complaints and applications of citizens and legal entities (Kyrgyz Republic President, 2021).

According to the majority of scientists, the definition of the concept of "judicial power" is closely interconnected with such categories as "justice", "court" and "judicial system". Along with this, the content of these institutes for a long time was interpreted quite ambiguously, and the definitions on this score in the domestic scientific literature have never been clear. Of the three powers, the judiciary is the weakest. It does not have power structures for coercion, like the executive power, and does not rely on the will of the voters, like the legislative power. The strength of the judiciary is the respect of a civilized society for the court and law as its just applicator and professional interpreter (Asankulova, 2015). The resolution of various conflict situations between participants in public relations based on the norms of law, which is carried out by specially authorized government power bodies, was considered as one of the priority areas of government activity at all times.

\section{Government Activity in the Judicial Issues}

In modern society, the most important element in the structure of this direction of government activity is the judicial method of settling disputes. The right to judicial protection is an absolute right, not subject to any limitation (Murzabe- 
kova, 2005).

In this regard, scientist V. Yakovlev notes that "the demand for judicial protection of the rights and interests of citizens turned out to be so great and the number of cases submitted to the courts is so great that the current judicial system does not fully cope with the volume of work" (Kurchenko, 2019). One of the problems of civil society at the present stage of development of Kyrgyzstan, as well as in Russia, is the distrust of our citizens to the judicial authorities, the judicial system as a whole. Adoption of unjust decisions and non-enforcement of fair court decisions are the main reasons for this mistrust (Grebnev, 2015). Thus, in Kyrgyzstan, following the results of the Plenum of the Supreme Court of the Kyrgyz Republic, in 2020 alone, a total of 68 judges were brought to disciplinary responsibility: 61 were warned, two were reprimanded, four were reprimanded, and one was early dismissed. Also concerning three judges, consent was given to be prosecuted (Supreme Court of the Kyrgyz Republic, 2021).

\section{Judges Activity}

On the other hand, many ordinary citizens have a low level of legal culture due to the lack of practical experience and legal education, and therefore they are often unable to convey to the judge the details of the event, which causes a rude, irritable attitude and disrespectful commentary on the situation by the judge.

Despite this, judges must show their high level of professional legal culture, the proper level of moral and ethical qualities, the Code of Honor of a Judge should serve as a guide for the conduct of judges. According the Code of Honor of a Judge of the Kyrgyz Republic, the main task of a judge is to administer justice. Throughout his term of office, a judge must not carry out any other activity that could call into question his independence and impartiality and lead to a conflict of interest (Judicial Department of the Supreme Court of the Kyrgyz Republic, 2017). In this regard, it should be noted that the bearers of the judicial power judges should be aware that they are guarantors of ensuring the right of citizens to judicial protection (Kyrgyz Republic Ministry of Justice, 2013).

The degree of protection of citizens directly or indirectly depends on the level of legal awareness, legal culture, positive thinking of a judge, and in general on his professionalism. The personality of a judge as a bearer of judicial power is associated with models, standards of people who differ from other specialists law enforcers in their contribution to the resolution of social conflicts and the organization of social reality in the legal framework through analysis and assessment, formalization of this government in acts of the judiciary decisions, decisions and sentences.

Thus, only government bodies established following the procedure established by the Constitution of the Kyrgyz Republic and constitutional laws are vested with judicial power. The first condition for the legitimacy of judicial power is the formation of a judicial body in the manner prescribed by law. 


\section{Court Structure}

The court is composed of judges carriers of judicial power, officials vested with judicial powers as a result of the application of a special procedure, performing their duties on a professional basis. In addition, clause 6 of article 26 of the Constitution of the Kyrgyz Republic states that everyone has the right to a trial by a court with the participation of a jury in cases provided for by law (Kyrgyz Republic Ministry of Justice, 2010).

The Constitution of the Kyrgyz Republic lays down the foundations for the consideration of criminal cases with the participation of jurors: "Everyone has the right to a trial by a court with the participation of a jury in cases provided for by law" and a law of the Kyrgyz Republic "On juries in the courts of the Kyrgyz Republic" was adopted, in connection with corresponding additions and changes were made to some legislative acts of the Kyrgyz Republic (Kyrgyz Republic Ministry of Justice, 2009).

The lack of proper administrative procedures in the practice of public authorities is the most difficult practical task of public administration, which directly affects such fundamental areas as the creation of a favorable business environment (Kyrgyz Republic Program, 2013). In Kyrgyzstan, there is still a strict selection according to criteria far from professional training, clan, regional affiliation, discourages the desire to work effectively, due to which the degree of mobility of the bureaucratic apparatus is extremely reduced (Aidarbekova \& Toktobaev, 2019).

To democratize legal proceedings, strengthen its competitiveness and transparency, reduce negative aspects of judicial errors, corruption and abuse by the judiciary, it is necessary to involve wide layers of citizens in the administration of justice with the participation of the people (non-professional judges) in the criminal process has been known since ancient times. Therefore, judicial practice is a traditional source of legal regulation (Egorov, 2018) that occupies a decisive place in classical legal systems. It was she who formed the directions of development of the legal system, ensured a constant, mutual connection of legislation with the dynamics of social relations.

\section{Jury Models}

Educational and educational functions play an important role in the jury of the continental model since the joint session of the jury with the crown judges allows the jury to adopt the legal culture and legal knowledge that professional judges have. In the Kyrgyz Republic, on the other hand, the issue of organizational support of judicial activism has been one of the main issues of judicial reform for almost several years.

The institution of the jury of the Kyrgyz Republic in many respects meets the requirements of the institution of civil law, as in cases considered by the jury, the mandatory participation of the prosecutor in the trial, which performs the func- 
tion of supporting the government prosecution (Batyrbaev, 2017). The complete refusal of the prosecutor from the charge entails the termination of the criminal case by the presiding judge at the stage of the trial. Such a decision is made by the judge when the prosecutor refuses to charge at the preliminary hearing or as a result of the trial of a criminal case by a court with the participation of a jury.

A jury trial in Kyrgyzstan refers to the Romano Germanic system for the application of codified legislation and, in structure, to the Anglo Saxon functioning separately as a judge-law and a judge-fact. The Kyrgyz Republic legislation provides for nine jurors and one judge of law, taking the Anglo Saxon model as an example. A jury session independently renders a verdict independently, and a judge of law (a professional judge) renders only a verdict. Educational and educational functions play an important role in the continental model jury, since the joint jury session with the crown judges allows the jury to adopt the legal culture and legal knowledge that professional judges have (Kyrgyz Republic Ministry of Justice, 2009). During the period of the country's development as a sovereign, independent state, the judicial system of the Kyrgyz Republic has undergone significant changes. One of the key moments of the judicial and legal reform, carried out in the Kyrgyz Republic in recent years, was the adoption of significant changes in the criminal procedure code of the Kyrgyz Republic. The novelty in the Code of Criminal Procedure of the Kyrgyz Republic is the section "Features of production about legal entities".

For the first time, the process of applying measures of criminal law to a legal entity is carried out within the framework of pre-trial proceedings (Kyrgyz Republic Ministry of Justice, 2017; Salybekova, 2020). The application of measures of a criminal-legal nature to a legal entity becomes possible subject to its recognition as a subject of criminal law. Today, an attempt is being made to bypass this moment, significant for criminal law, by applying to a legal entity but not a criminal punishment, but measures of a criminal-legal nature, which formally do not belong to criminal punishments, but are essentially measures of criminal coercion by the state (a criminal sanction).

The application of criminal liability to legal entities will facilitate the adoption by legal entities of additional measures of corporate control over their officials of the management bodies, thereby solving the problem of crime prevention in legal entities.

Changes in domestic legislation, which is now guided by the court in the administration of justice, and with structural modifications of the judicial system itself, its functions include refusal of the supervision of the prosecutor's office and initiative supervision, the unification of courts of general jurisdiction and former arbitration courts into an integral judicial system, the creation of the institution of appeal, change mechanism for the selection of judges, etc. (Toktombaeva, 2014).

\section{Conclusion}

Summing up, we note that legal scholars consider it necessary to introduce into 
the definition of the judiciary a different number of characteristics, the totality of which reflects, in their opinion, the essence of justice. Each of the above characteristics, in one way or another, helps to reveal the content of the judiciary. And yet, whatever the list of signs, it can always be expanded by a certain kind of detail. It can be said about individual signs that they cannot be necessary attributes of the definition of judicial power.

In our opinion, there is no need to indicate in the definition of the judiciary that it is a state activity. The very fact that only the court administers justice proves the government character of the latter. In the legal policy of the Kyrgyz Republic, the first steps have begun on the reform of public administration measures which have been taken to reduce the number and funds for the government apparatus maintenance, with introduction of new modern technologies and management methods into the system of government bodies called as "single window", "electronic government", introduction systems "Tunduk", "Safe City", "Smart City", etc.

Despite these positive moments, the methods of management in the executive power system cause sharp criticism from the citizens of the republic, since they do not allow to respond promptly to any challenges and threats, such as the COVID19 pandemic, and to solve emerging problems.

\section{Conflicts of Interest}

The authors declare no conflicts of interest regarding the publication of this paper.

\section{References}

Aidarbekova, G. B., \& Toktobaev, B. T. (2019). Anti-Corruption Legal Policy of the Kyrgyz Republic (Comparative Analysis). Bulletin of Science and Practice, 5, 382-389. https://doi.org/10.33619/2414-2948/42/52

Amanbaev, B. (2020). It Is Necessary to Create New Mechanisms for Organizing the System of Public Administration. https://www.gov.kg/ru/post/s/baktybek-amanbaev-neobkhodimo-sozdat-novye-mekha nizmy-organizatsii-sistemy-gosudarstvennogo-upravleniya

Asankulova, Z. Z. (2015). Theoretical Aspects of the Judicial Power. Bulletin of Scientific Conferences, 3-7, 5-8.

Batyrbaev, B. S. (2017). Judge of Fact in Criminal Proceedings in the Kyrgyz Republic. Ala-Too Academic Studies, 4, 141.

Egorov A. V. (2018). Domestic Law of Foreign States as a Source of Private International Law. Journal of Russian Law, No. 6, 105-114. https://doi.org/10.12737/art 2018610

Ganieva, T. I. (2019). Reforms in the System of Public Administration in the Kyrgyz Republic. Bulletin of Science and Practice, 5, 376-385.

https://doi.org/10.33619/2414-2948/43/50

Grebnev, R. D. (2015). Judicial Power in the Structure of the State Mechanism and in the System of Separation of Powers. In Bulletin of the Peoples Friendship University of Russia. Series: Legal. Science, Moscow, 51.

Judicial Department of the Supreme Court of the Kyrgyz Republic (2017). Code of Honor 
of a Judge of the Kyrgyz Republic.

http://suddep.sot.kg/post/kodeks-chesti-sudi-kyrgyzskoj-respubliki

Kuldysheva, G., Minbaev, S., Paraidinuulu, S., Mirzaeva, A., Atantaev, A., Rustam, M., Amanbek, K., Abdullaeva, Z., \& Toktobaeva, E. (2021). Kyrgyz Customary Law Development. Open Journal of Social Sciences, 9, 321-327.

https://doi.org/10.4236/jss.2021.91023

Kurchenko, V. N. (2019). Mistake of Justice: Responsibility, but Not Right. Russian Law: Education, Practice, Science, 3, 4-17. https://doi.org/10.34076/2410-22709-2019-3-4-17

Kyrgyz Republic Ministry of Justice (2009). Kyrgyz Republic Law "On Jurors Courts of the Kyrgyz Republic from July 15, No. 215.

http://cbd.minjust.gov.kg/act/view/ru-ru/202673/10?cl=ru-ru

Kyrgyz Republic Ministry of Justice (2010). Kyrgyz Republic Constitution. http://cbd.minjust.gov.kg/act/view/ru-ru/202913

Kyrgyz Republic Ministry of Justice (2013). National Strategy on Sustainable Development of the Kyrgyz Republic for the Period 2013-2017.

http://cbd.minjust.gov.kg/act/view/ru-ru/61542

Kyrgyz Republic Ministry of Justice (2017). Decision of Constitutional Ward of Supreme Court on Behalf of the Kyrgyz Republic.

http://cbd.minjust.gov.kg/act/view/ru-ru/9677?cl=ru-ru

Kyrgyz Republic President (2021). Constitution. http://www.president.kg/ru/konstituciya

Kyrgyz Republic Program (2013). For the Transition to Sustainable Development for 2013-2017. http://cbd.minjust.gov.kg/act/view/ru-ru/53067

Marques, I., Leitão, J., Carvalho, A., \& Pereira, D. (2021). Public Administration and Values Oriented to Sustainability: A Systematic Approach to the Literature. Sustainability, 13, 2566. https://doi.org/10.3390/su13052566

Ministry of Foreign Affairs of the Kyrgyz Republic (2018). National Development Strategy of the Kyrgyz Republic for 2018-2040: Approved by the Decree of the President of the Kyrgyz Republic on October 31.

https://mfa.gov.kg/ru/osnovnoe-menyu/vneshnyaya-politika/gosudarstvennye-progra mmy/nacionalnaya-strategiya-razvitiya-kyrgyzskoy-respubliki-na-2018-2040-gody

Murzabekova, Z. T. (2005). Environmental Law (p. 43). Bishkek: Textbook.

Napalkova, I. G. (2018). Formal Legal Method as the Basis of the Methodology of Legal Positivism. Philosophy of Law, 3, 7-12.

Rossinsky, B. V. (2007). Legal Boundaries in the Activities of State Bodies in the Implementation of Control and Supervisory Activities. In E. G. Yasin (Ed.), VIII International Scientific Conference. Modernization of the Economy and Social Development (pp. 479-484). Moscow: Publishing House of the State University Higher School of Economics.

Russian Law Academy of the Ministry of Justice of the Russian Federation (2021). Basic Methods of Legal Science. https://distance.rpa-mu.ru/files/mg/imun/thm/tsm11.html

Salybekova, T. S. (2020). Institute of Criminal Liability of Legal Entities under the Criminal Law of the Kyrgyz Republic. Bulletin of Science and Practice, 6, 347. https://doi.org/10.33619/2414-2948/52/44

Supreme Court of the Kyrgyz Republic (2021). Plenum Held on February 26. http://sot.kg/post/sostoyalsya-plenum-verhovnogo-suda-kyrgyzskoj-respubliki-3

Toktombaeva, A. Zh. (2014). Constitutional Principles of Justice and Their Implementation in Criminal Proceedings of the Kyrgyz Republic (47 p). Dissertation, Bishkek: 
Kyrgyz National University Named after J. Balasagyn.

Ukushev, M. A. (2018). Harsh Choice for Kyrgyzstan: A Catastrophe or Modernization of the Government. Part 3, Elgezit Newspaper.

https://elgezit.kg/2020/08/13/surovyj-vybor-dlya-kyrgyzstana-katastrofa-ili-modernizat siya-gosudarstva-chast-3 